International Journal of Linguistics, Literature and Culture
Available online at https://sloap.org/journals/index.php/ijllc/
Vol. 5, No. 6, November 2019, pages: 28 35
$\begin{aligned} & \text { ISSN: 2455-8028 } \\ & \text { https://doi.org/10.21744/ijllc.v5n6.749 }\end{aligned}$

\title{
Ideology Behind the War of Puputan Badung
}

A. A. Ketut Adi Antara ${ }^{\text {a }}$

I Putu Gelgel ${ }^{\text {b }}$

I Wayan Budi Utama ${ }^{c}$

Article history:

Received: 18 May 2019

Accepted: 31 July 2019

Published: 19 September 2019

\section{Keywords:}

conservatism;

ideology;

literary;

puputan badung;

war;

\begin{abstract}
This research was intended at exploring the ideology behind the war of Puputan Badung. The researchers observed, there were many questionsideological regarding the attitude of the King and his retinue in conducting puputan. Therefore, the expression of the ideology behind Puputan Badung was very interesting to study. There were three problems are investigated, namely (1) the ideology behind the war of Puputan Badung, (2) the process of implanting the Puputan Badung ideology, (3) the Puputan Badung implementation in the current context. These issues were discussed using several theories namely, the theory of power relations and knowledge, and the theory of deconstruction. This research on its implementation used a qualitative approach. In terms of data analysis, the emphasis was not on measurement but on efforts to describe and explore the various meanings behind socio-cultural actions carried out by humans. The results study showed that the ideology behind the war of Puputan Badung namely, wirang, honor, Rana Yadnya dan Mati Tan Tumut Pejah, and conservatism. The ideology implantation was conducted through several mediums namely, puppetry, literary work, family, and government.
\end{abstract}

2455-8028 ${ }^{\circledR}$ Copyright 2019. The Author. This is an open-access article under the CC BY-SA license (https://creativecommons.org/licenses/by-sa/4.0/) All rights reserved.

\section{Author correspondence:}

A. A. Ketut Adi Antara,

Universitas Hindu Indonesia, Denpasar, Indonesia.

Email address: a.a.adiantara@gmail.com

\section{Introduction}

In 1960, there was a great war in Badung (regency in Bali Island of Indonesia). The war between King Badung and Dutch. This war is known as the Badung Puputan. Puput in Balinese means to run out, break up, and die. The word puput gets the suffix 'an' become puputan also means done or finished. The puputan means all-out war or the war to the death in the face of an enemy, based on a sincere struggle with all the sacrifices including the most valuable property of soul and body, for the sake of truth and independence (Sudarta et al., 2001).

${ }^{a}$ Universitas Hindu Indonesia, Denpasar, Indonesia

${ }^{\mathrm{b}}$ Universitas Hindu Indonesia, Denpasar, Indonesia

${ }^{\mathrm{c}}$ Universitas Hindu Indonesia, Denpasar, Indonesia 
The war of puputan in Bali is known as an all-out struggle against all kinds of colonialism and conquest from outsiders, in this context, it was the Netherlands. The war on puputan heroism is not only happening in Badung but also in other areas in Bali unlike, Klungkung and Buleleng. It means the ideology of puputan is used by kings and the Balinese people to fight (Agung, 2001; 1989; 1991). Puputan is like an ethos of self-preservation and identity as a Balinese.

The war of puputan is marked by the extraordinary sacrifice for all people who love their region, both life, and material sacrifice. The war is conducted if the Balinese people in order to defend their area from the occupation of the Dutch colonial government. In the $19^{\text {th }}$ century, there were in Bali many kingdoms, each of which had its own power. The kingdoms include Buleleng, Karangasem, Klungkung, Gianyar, Bandung, Tabanan, Mengwi, Bangli, and Jembrana.

Buleleng, Klungkung and Badung kingdoms fought aggressively against the Dutch. The kings in Bali are bound by an agreement called Hak Tawan Karang namely the right of a country to recognize and own ships stranded on its territory. The right triggers a war with the Netherlands. In 1844, the Dutch trading boat was stranded in Prancak, the area of Buleleng Kingdom and subject to Hukum Tawan Karang (law). The law gives the royal authorities the right to control the stranded ship and its contents (Junaidi, 2018; Purnaya, 2016).

The Dutch had strong reasons to carry out an attack on the Buleleng Kingdom in 1848. However, the people of Buleleng were able to fend off the attack. The second attack in 1849, the Dutch troops led by General-Major A.V. Michies and Van Swieeten succeeded in capturing the last stronghold of Buleleng Kingdom in Jagaraga. The massive attacks, the people of Bali retaliated with a total war to maintain their dignity as Balinese. The war to defend Buleleng was known as Puputan Jagaraga. Other puputan, namely Puputan Badung (1906), Puputan Kusamba (1908), and Puputan Klungkung (1908).

Puputan Badung is also one of the most heroic events in Bali. The King Badung was Cokorda Mantuk Ring Rana performed puputan with hundreds of escorts. The King Badung previously hid in Pura Satria (temple name) with hundred women and men who were wearing white clothes, their armed were spear and creese. Then, they were out to the main road, in front of Pura Satria (temple name) awaited the arrival of the soldiers, defining that they will 'mepuputan' on the battlefield. The soldiers at 7 am was leaving from Puri Kesiman (castle name) would attack Denpasar.

There were guarded in Kali Ungu by several Badung people who were armed with spear and creese. It was including armed guns. The soldiers never stopped attacking. Many Badung troops death and injuries, while from the company a gunshot wounded. The soldiers at 11 am or a half days entered Taensiat to war for only 1.30 hours. The enemy retreated until where the road ahead of Pura Satria. Wherein the King Badung was waiting to sit on a palanquin carried by someone. It was accompanied by thousands of women with spear guns and creese. The soldier did not decide to throw the bullet, therefore, the King Badung was piled to death due to 'mepuputan'.

The mass puputan was conducted showing that there was an ideology maintained both the King and his followers. An ideology is a system of ideas, values, and opinions believed by certain groups (Latupeirissa et al., 2019; Dasih et al., 2019). The term mati tan tumut pejah by Cokorda Mantuk Ring Rana shows the King has a dignity that cannot be offered by anyone including the Dutch government. Mati tan tumut pejah is also interpreted as an effort to uphold dharma and look for authenticity in life (Agastya, 2006). However, the term mati tan tumut pejah certainly could not represent the mystery of the mass puputan of the king at that time. The researchers observed, there were many questions-ideological regarding the attitude of the King and his retinue in conducting puputan. Therefore, the expression of the ideology behind Puputan Badung was very interesting to study. There were three problems are investigated, namely (1) the ideology behind the war of Puputan Badung, (2) the process of implanting the Puputan Badung ideology, (3) the Puputan Badung implementation in the current context.

\section{Materials and Methods}

This research used a qualitative approach. The data collection was carried out through library studies related to the history of Puputan Badung, interviewed with the descendants of the King who did puputan. The author as well as interviewed historians who had a concentration on the war of Puputan Badung. Data analysis is performed after the collected data using a descriptive-analysis method (Maimun et al., 2018; Suryasa et al., 2019).

Antara, A. A. K. A., Gelgel, I. P., \& Utama, I. W. B. (2019). Ideology behind the war of puputan badung. International Journal of Linguistics, Literature and Culture, 5(6), 28-35. https://doi.org/10.21744/ijllc.v5n6.749 


\section{Results and Discussions}

\subsection{Ideology Behind the War of Puputan Badung}

The historical data observations and interviews with informants can be explained that the ideology behind the war of Puputan Badung is firstly wirang or heroic nature that became the ethos of King Badung's leadership at that time. The character of heroism has been shown when the King Denpasar and Badung took action against the Dutch who negotiated related to compensation for the lost money of 3000 ringgit on Sri Komala Ship which landed in Sanur. The refusal to negotiate and pay compensation is based on the principle of truth is believed by the King. It was not true that his party and people looted and took money that was on Sri Komala ship. The point was the King feels innocent and did not need to pay compensation.

The Kings of Denpasar and Badung refusal was made to negotiate the Dutch. It can be stated to be a heroic decision-showing the heroism spirit. Although they did not have complete and sophisticated war equipment at the time, the courage to put up resistance reflected the wira attitude (hero) facing threats came from outside, including colonial threats. If it is examined the King attitude at that time was shown the view of life and the values that he believed as tedung jagat. The heroic values indicate that the King understands the name of wira rasa (heroism sense) that must be stirred up when facing colonialism. The ideology of wirang is at its peak when the King conducted puputan/fights to the last blood against colonialism.

The King of Badung on September $20^{\text {th }}, 1906$ was praying at Pura Satria with hundred women and men who were wearing white clothes and armed with spear and creese, after going out into the main road, the front of Pura Satria awaiting the soldier's arrival, defining that they would 'mepuputan' on the battlefield. Then, the soldiers at 7 am was leaving from Puri Kesiman will attack Denpasar.

Second, is honor and self-esteem. The other ideology of heroism, the war of Puputan Badung also cannot be separated from the matter of the honor and dignity of the King and his people at that time. As it is known, the Kings in Bali have high respect in the people's view. The honor and dignity can be seen culturally, the title of King, speech manner, etc. The honor and dignity can also be seen when the King chose to die rather than having to entry to the Netherlands Indies Government. This attitude is not only a matter of principle and heroism but also defends the honor and dignity of power at that time. Even though at that time, another King in Bali had advised the King Badung to submit to the government's decision, but it was not followed by the King Badung. If it is examined the attitude of the King Badung at that time showed how high the honor and dignity of the King and his people. Although he had to deal with the Dutch East Indies government, the King Badung was never afraid to conduct a confrontation on the basis of truth that was believed. The honor and dignity of the people are more important than war deaths. The high value of the King's honor and dignity was raised in the form of war of puputan, mabela pati, against all colonialism types conducted by the Dutch. It can be stated that the price of the King's honor and his people at that time was death.

Third, it is Rana Yadnya dan Mati Tan Tumut Pejah. The decision of King Badung I Gusti Ngurah Made Agung or called Cokorda Mantuk Ring Rana was to conduct puputan facing the Netherlands cannot be separated from the view of life and he believes the values so far away. The value system is conveyed through literary works namely, poetry, geguritan, and so on. It is, for example, Geguritan Dharma Sasana, Geguritan Niti Raja Sasana, Geguritan Nengah Jimbaran, Kidung Loda, Kakawin Atlas, and Geguritan Hredaya Sastra. Literary works were written by Cokorda Mantuk Ring Rana. The expressions of attitudes and values greatly influence his outlook on life. The war of Puputan Badung is greatly influenced by the thoughts of King Badung as set forth in his literary work. The war is not only on heroism form but also the main yadnya (offerings).

King Badung understood the philosophy regarding Rana Yadnya or the battlefield as a ceremonial field. The ceremonial field was made by the King as a yadnya. It is stated a battlefield is a holy place dedicated to the truth itself. King Badung valiantly carried out puputan with his people. Fourth, there is a conservatism. It is a political ideology. It requires tradition or culture to be preserved, maintained, and preserved. The change did not always mean progress. Therefore, It should take place step by step, without destabilizing a political structure in the country or society concerned.

This ideology is usually only applied as a basis for certain groups, not as a basis for the state. The characteristics of the conservatism ideology teach the importance of royal institutions as the main force. The efforts are to preserve traditions and customs in the way of people life. There are established institutions unlike, the family and state are all considered sacred. The was of Puputan Badung is also inseparable from the conservative ideology behind it. This 
conservative ideology intends to maintain traditional values, it is for the political system and government. One of the traditional values is the monarchy or royal government system, considering before Indonesia implemented the republic system. The state was led by a King.

\subsection{Implanting of Puputan Badung Ideology}

The implanting of Puputan Badung ideology is conducted through several mediums namely firstly, puppetry. As a litterateur, Cokorda Mantuk Ring Rana is very interested in literary works including puppets. The field of puppetry is very effective as a medium for implanting religious literary values at that time. Moreover, it is known, puppetry has been very included in the culture of the Indonesian people. The implanting of ideology, especially Puputan Badung cannot be released from puppet media. Moreover, as it is above explained, existed puppetry of the royal era became very popular performing arts. Through puppetry media, the Balinese are educated about the values of truth, morality, ethics, and religion. It is included the Kings in Bali, for example, literary works. They understand the values of leadership and heroism through puppet shows. This view is justified by a number of sources in the present study. One of them is Ida Bagus Ngurah Dharma Putra. He stated that the implantation of the values of heroism, leadership, and the ethos of the current struggle is very much influenced by literary and artistic works. Especially, for the arts, shadow puppet shows are very popular. Through the puppetry performance, the puppeteer conveys the contents of the Mahabharata and Ramayana stories, especially, those related to truth values. In Bali, the stories contained on Asta Dasa Parwa are very popular to the societies. The shadow puppets performance also took the stories in the Asta Dasa Parwa.

Second, there are literary works. The other than puppet media, the implantation of puputan on King Badung cannot be separated from the world of literature. Especially, the among enthusiasts of literary works in Bali, King Badung I Gusti Ngurah Made Agung who perform puputan is known as a great litterateur. The King Badung is also very close to Ida Pedanda Made Sidemen. He was a great Balinese author whose works in the form of kakawin much appreciated and studied. He was authored some kakawin namely, Kakawin Cahyadijaya, Kakawin Candrabhairawa, Kakawin Singhalanggyala, Kakawin Kalpasangara, Kakawin Patitip, Purwagama or Siwabhudagama, Kidung Tantri Pisacarana, and Geguritan Salampah Laku. The interesting is two authors also wrote literary works related to Sanghara (destruction period). They had been known to be friends with Ida Pedanda Made Sidemen, King Badung also familiar with Parwa's literary texts.

Cokorda Mantuk Ring Rana is very interested in Kakawin Bharatayuda by Mpu Sedah and Mpu Panuluh in 1157. It was obtained in this literary work description of rana yadnya (battlefield) as a ceremonial field. It can be stated that Cokorda Mantuk Ring Rana was greatly influenced by the two literary works, including inspiring their authorship. He was reading literary works, especially, Bharatayuda, King Badung understood war as rana yadnya, or the field of yadnya. In the field of yadnya, he was presented on the battlefield for truth. Third, there is family and government. The implantation of Puputan Badung ideology can also be conducted through two institutions namely the current government and family environment. The implanting of ideology is very delicate, therefore, the internalization process also takes place slowly. The government and family environment, the king descendants were instilled in the values of leadership, heroism, religion, moral ethics, and so on. Especially, as it is well known, inside the palace, there are value systems and cultural systems. They are run inside the palace. The cultural system greatly influenced the palace residents, for their families and their people.

\subsection{Ideology of Puputan on the Current Context}

The ideology of Puputan Badung in the present context can be seen through several events and ceremonies. First, there was the war of Puputan Margarana. Even though Puputan Badung occurred in 1906, two years later, it was followed by King Klungkung in 1908. Even, in 1946, it was inspired the fighters to conduct the war of puputan known as the Puputan Margarana. The spirit of puputan continues to surge and inspire the heroes struggle to defend the country and its homeland. The ideology of puputan initially tended to be used to maintain self-esteem and truth values. There were believed, during pre-independence Indonesia, were used as an ethos of struggle in the context of defending the nation and state. It shows that Puputan Badung incident inspired further struggles dealing with invaders. The ideology of puputan continues to be contextualized in the context of defending the nation and the state, including upholding Pancasila and Bhineka Tunggal Ika (unity in diversity).

Second, there is a ceremony of Puputan Badung. One of the efforts is to remember and implement the value system. It is to always commemorate the event of Puputan Badung. The ceremony is not only conducted to preserve

Antara, A. A. K. A., Gelgel, I. P., \& Utama, I. W. B. (2019). Ideology behind the war of puputan badung. International Journal of Linguistics, Literature and Culture, 5(6), 28-35. https://doi.org/10.21744/ijllc.v5n6.749 
the historical memory of the courage of the King and his followers on resisting the occupation but also as a place to fill the struggle of Puputan Badung in the present context. Actually, there is through a ceremony of Puputan Badung. The efforts are to elaborate and reinterpret the ideology of Puputan Badung continually. The spirited event continues to be encouraged through a ceremony. As it is known, the Government of Denpasar City has an annual schedule, especially, which coincides the ceremony on Puputan Badung. The memorial is filled with various kinds of cultural events, from competitions to cultural performances.

It was conducted as an effort to continue maintaining and caring for the memories of the present generation on Puputan Badung event. It is hoped surely the puputan spirit continues to be encouraged in the present context. There is usually the cultural schedule on the commemoration of Puputan Badung is held right on Catuspata Banjar Taensiat. Wherein, there is now a statue of I Gusti Ngurah Made Agung. Third, there is through environmental action. The interpretation of puputan spirit is appropriate to the current context. It can not only be seen from the war of Puputan Margarana events and activities towards Puputan Badung commemoration, but there are also social movements in Bali. It defines that the emergence of social movements in Bali is based on development issues brings the puputan spirit as its ideological basis.

The social events specifically for Bali has also required an ideological foundation. There is puputan. This is at least reflected through the refusal actions of tourism accommodation development took place in Bali. The refusal was based on several reasons, for example, environmental and cultural reasons. The ideology of puputan was adopted as a spirit to fight for Bali preservation from the threat of tourism industrialization.

\section{Conclusion}

The war of Puputan Badung is rich on heroic values. There is an underlying ideology. The ideology behind the war of Puputan Badung is firstly, wirang or heroic nature became the leadership ethos of King Badung at that time. Second, it is honor and self-esteem. The other is heroism ideology. The war of Puputan Badung also cannot be separated from the matter of the honor and dignity of the King and his followers at that time. Third, it Rana Yadnya and Mati Tan Tumut Pejah. The decision of King Badung I Gusti Ngurah Made Agung or called Cokorda Mantuk Ring Rana was to conduct puputan facing the Netherlands cannot be separated from the view of life and he believes the values so far away. The value system is conveyed through literary works included poetry, geguritan, and so on. Fourth, it is conservatism. It is a political ideology, which requires tradition or culture to be preserved, maintained, and preserved.

The implanting of Puputan Badung's ideology is conducted through several mediums namely, first, puppetry. As a litterateur, Cokorda Mantuk Ring Rana is very interested in literary works including puppets. The world of puppets is very effective as a medium for implanting values at that time. Second, it is literary works. The other than puppet media, the implanting of puputan towards the King Badung cannot be separated from the world of literature. Especially, the among enthusiasts of literary works in Bali, King Badung I Gusti Ngurah Made Agung who perform puputan is known as a great litterateur. Cokorda Mantuk Ring Rana is very interested in Kakawin Bharatayuda by Mpu Sedah and Mpu Panuluh in 1157. There is in the literary works, he got a description of rana yadnya or the battlefield as a ceremonial field. Third, there are family and government. The implanting of Puputan Badung's ideology can also be done through two institutions namely, the current government and family environment.

The ideology of Puputan Badung on the current context can be seen through several events and warnings. First, there was the war of Puputan Margarana. Second, there was a ceremony of Puputan Badung. One of the efforts to remember and implement the value system on the war of Puputan Badung is to always commemorate it. Third, there is through environmental action. 
Conflict of interest statement

The authors declared that they have no competing interest.

Statement of authorship

The authors have responsibility for the conception and design of the study. The authors have approved the final article.

\section{Acknowledgments}

The authors would like to thank the editor of IJLLC for their valuable time, support and advice.

Antara, A. A. K. A., Gelgel, I. P., \& Utama, I. W. B. (2019). Ideology behind the war of puputan badung. International Journal of Linguistics, Literature and Culture, 5(6), 28-35. https://doi.org/10.21744/ijllc.v5n6.749 


\section{References}

Agastya, M., \& McAfee, R. P. (2006). Continuing wars of attrition. Available at SSRN 935970.

Agung, A. A. G. P. (2001). Peralihan sistem birokrasi dari tradisional ke kolonial. Pustaka Pelajar.

Agung, A. A. K. (1991). Kupu-kupu kuning yang terbang di Selat Lombok: lintasan sejarah Kerajaan Karangasem, 1661-1950. Upada Sastra.

Agung, I. A. A. G. (1989). Bali pada abad XIX: perjuangan rakyat dan raja-raja menetang kolonialisme Belanda, 1808-1908. Gadjah Mada University Press.

Dasih, I. G. A. R. P., Triguna, I. B. G. Y., \& Winaja, I. W. (2019). Intercultural communication based on ideology, theology and sociology. International Journal of Linguistics, Literature and Culture, 5(5), 29-35. https://doi.org/10.21744/ijllc.v5n5.738

Junaidi, L. M. (2018). Stereotypes as the Ideology of Feminism in Novels Authorized by Indonesian Female Authors. International Journal of Linguistics, Literature and Culture, 4(1), 1-15.

Latupeirissa, D. S., Laksana, I. K. D., Artawa, K., \& Sosiowati, I. G. A. G. (2019). Revealing ideology of political speech. International Research Journal of Management, IT and Social Sciences,6(2), 79-91. https://doi.org/10.21744/irjmis.v6n2.654

Maimun, M., Mandala, H., \& Arifuddin, -. (2018). Ideology in tempo magazine advertising: a critical discussion analysis. International Research Journal of Management, IT and Social Sciences, 5(6), 40-51. https://doi.org/10.21744/irjmis.v5n6.336

Purnaya, I. G. K. (2016). The ideology that affects the management of tourist resort Nusa Dua-Bali. International Journal of Linguistics, Literature and Culture, 2(4), 72-80.

Sudarta, D. R. P. (2001). Small and Medium Enterprice Clusters during the Economic Crisis in Indonesia (unpublished thesis). Institute of Social Science, The Hague.

Suryasa, I. W., Sudipa, I. N., Puspani, I. A. M., \& Netra, I. M. (2019). Translation of Krsna text and ideology. International Journal of Social Sciences and Humanities, 3(1), 36-47. https://doi.org/10.29332/ijssh.v3n1.251 


\section{Biography of Authors}

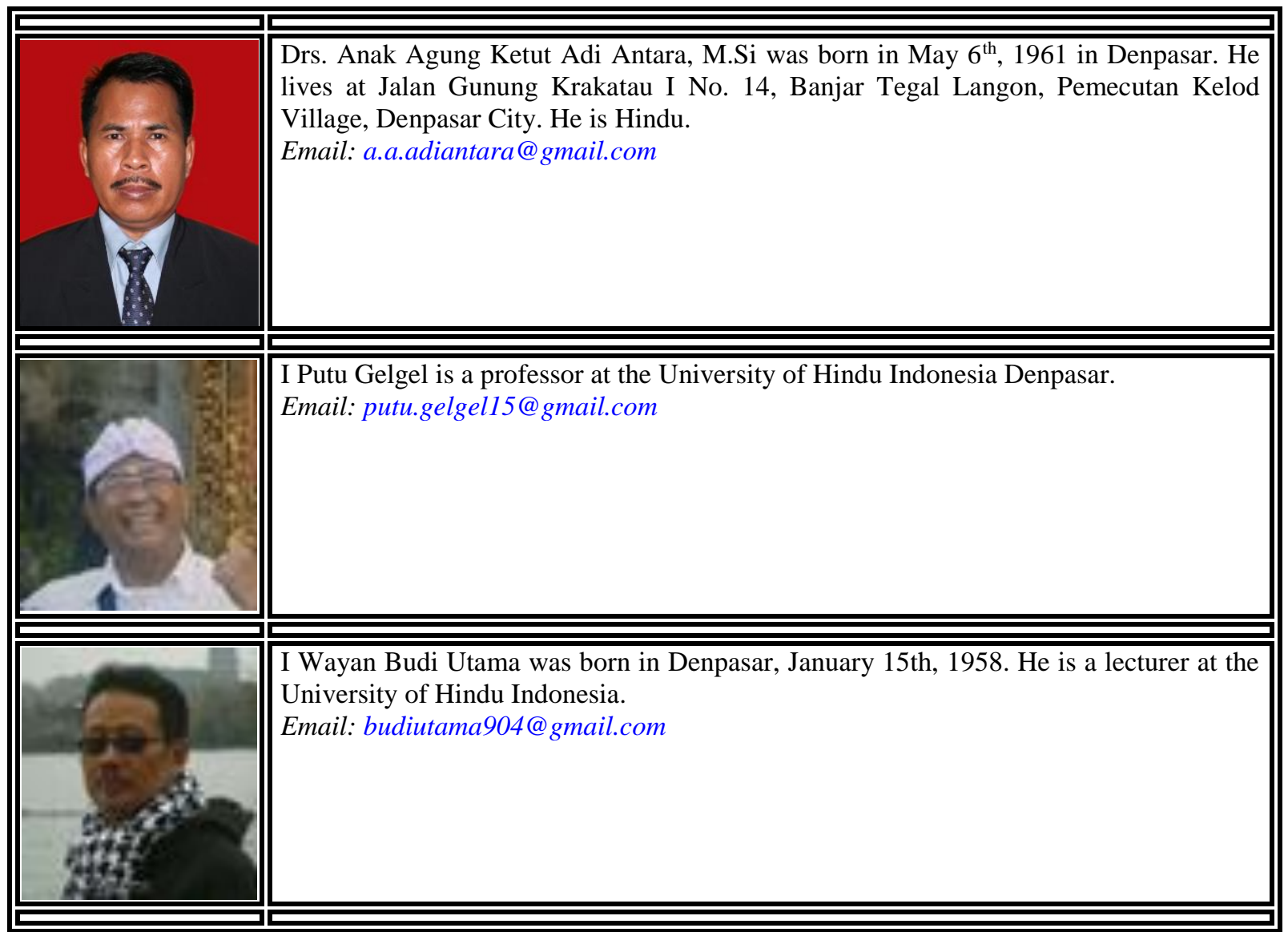

Antara, A. A. K. A., Gelgel, I. P., \& Utama, I. W. B. (2019). Ideology behind the war of puputan badung. International Journal of Linguistics, Literature and Culture, 5(6), 28-35. https://doi.org/10.21744/ijllc.v5n6.749 